\title{
Análisis del mensaje publicitario
}

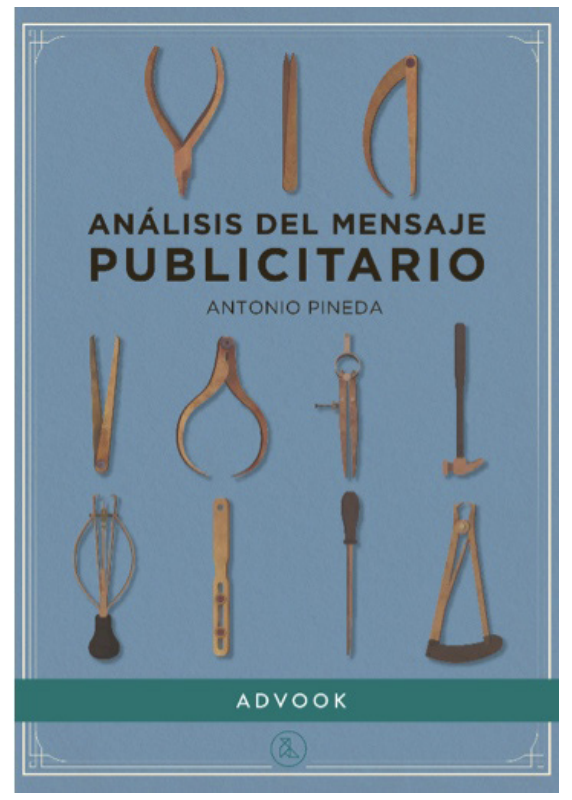

\section{Análisis del mensaje publicitario}

\author{
Antonio Pineda \\ Advook, Sevilla, 2018 \\ 235 páginas \\ Reseña por Elena Bellido-Pérez
}

El discurso publicitario abandona todo azar y superficialidad dentro del exhaustivo manual Análisis del mensaje publicitario, escrito por Antonio Pineda. El instrumental analítico que el autor pone a disposición de lectoras y lectores hace que el desmembramiento de las piezas publicitarias sea tan exquisito que agotar los pasos propuestos para el estudio del mensaje se convierte en una opción tan académicamente necesaria como fascinante. Dividido en diez capítulos, esta obra publicada en Advook ofrece nueve vías para emprender un análisis semiótico de la publicidad, elección de las cuales (de manera aislada o conjunta) dependerá de la naturaleza del anuncio escogido. El punto de partida que justifica este motivador acercamiento al significado del mensaje en la publicidad radica, precisamente, en la trascendencia de dicho mensaje, esto es, en la creencia de que existe un significado más allá de lo referencial. A esta premisa se le une la brevedad del formato publicitario, que obliga "a codificar una gran cantidad de significados en poco espacio y poco tiempo, de forma que la densidad semántica de un spot de 30 segundos o una gráfica de escasos centímetros cuadrados puede ser considerablemente elevada" (p. 17). Así pues, con el objetivo de captar la connotación en la brevedad publicitaria, el presente manual trae consigo una recopilación ordenada, pautada y esclarecedora de teorías semióticas que funcionan como herramientas para el análisis del mensaje publicitario en particular, pero también, en muchas ocasiones, del mensaje massmediático en general. 
De este modo, el libro comienza con los niveles de análisis de Roland Barthes, autor al que se le adjudica el logro de colocar la publicidad en una posición relevante dentro de los estudios semióticos. Según Barthes, en la publicidad nos encontramos una imagen denotada o literal, una imagen connotada o simbólica y un mensaje lingüístico (que, a su vez, puede ser denotado y connotado). La identificación de ese contenido simbólico siempre dependerá "del conocimiento cultural del receptor del anuncio" (p. 32) y, por ende, del analista, algo que puede tanto limitar como expandir excesivamente los significados asociados. No obstante, para evitar una extrema subjetividad en la connotación, el texto presente en el anuncio (gráfico, se recomienda escoger en este caso) suele tener una función de anclaje o relevo según Barthes.

En el segundo capítulo, Antonio Pineda aplica al discurso publicitario el estructuralismo, método cuyo objetivo es "la reconstrucción de un objeto mediante la manifestación de las reglas de funcionamiento y asociación de dicho objeto" (p. 56). Así, identificando como estructura un grupo cerrado de mensajes publicitarios, la o el analista deberá descomponer sus elementos y ordenarlos en un sistema de oposición binaria hasta reducir dichas relaciones a uno o varios mensajes. Lo más interesante de esta metodología es que revela "principios rectores profundos que pueden tener implicaciones diversas (ideológicas, por ejemplo)" (p. 61).

En tercer lugar, la transferencia de significado y la resemantización son las metodologías de análisis protagonistas. Ambas responden a la necesidad de insertar el producto o servicio publicitado en una red de significados de la que carece per se. La primera trata de relacionar el producto con otro signo "significativo y relevante de alguna forma para el público" (p. 68), y de cuyo significado se nutre. Por su parte, la resemantización consiste en "alteración del significado histórico que posee un signo, manteniendo el significante relativamente inalterado" (p. 74), lo cual puede llevar en ciertos casos a la banalización o desideologización de dichos signos bajo la premisa de fines comerciales.

La sintaxis narrativa de Algirdas Julien Greimas es la cuarta propuesta metodológica en la obra de Antonio Pineda. Esta gramática actancial permite el análisis del spot publicitario en función de los binomios sujeto/objeto, destinador/destinatario y ayudante/oponente, que "se relacionan entre sí mediante el Programa Narrativo (PN), es decir el [...] conjunto de estados y transformaciones relativos al sujeto que desea y al objeto deseado" (p. 91). Al contrario que las anteriores herramientas, esta no saca a la luz significados ocultos o latentes en el mensaje, pero sí operacionaliza la construcción de la narrativa publicitaria. En este sentido, Antonio Pineda propone cuatro interesantes hipótesis (pp. 99-100): el programa narrativo publicitario es un enunciado de transformación en el que (1) el Sujeto logra la conjunción con el Objeto, (2) el producto incrementará el conocimiento del Sujeto, y en el que (3) el producto es el Objeto o (4) el Ayudante de la acción.

Aplicando el recorrido generativo de Greimas que Antonio Pineda había presentado en el capítulo cuarto, Jean-Marie Floch describe cuatro filosofías publicitarias que se detallan en el siguiente capítulo. Estas son la publicidad referencial, en la que predomina una función representativa; la publicidad oblicua, donde esa función representativa se deniega en pro del pensamiento lateral del receptor; la publicidad mítica, en la que el anuncio construye su significado dentro de un marco cultural; y la publicidad sustancial, donde se pretende 
hacer referencia a la naturaleza profunda del producto. Floch también elabora un cuadrado semiótico de valores del consumo (valorización práctica, utópica, crítica y lúdica) que posteriormente retomará Andrea Semprini en su mapping semiótico de los valores del consumo, descrito en el capítulo sexto. En este mapping, Semprini utiliza los cuatro valores de Floch como puntos axiológicos y distingue, a su vez, cuatro identidades de marca: marcas de misión, de proyecto, de euforia y de información. Posteriormente, y para conocer la construcción semiótica de estas tipologías de marca, les aplica cinco elementos discursivos extraídos de Greimas: el tiempo, el espacio, los actores, las relaciones y las pasiones; este procedimiento da como resultado lo que Pineda denomina "indicadores empíricos del discurso de marca" (p. 129). "Gracias a estos elementos discursivos o superficiales, los valores de las marcas y las estructuras narrativas que éstas emplean reciben una configuración específica en los anuncios" (p. 129).

El séptimo capítulo está dedicado a la isotopía semántica, esto es, de nuevo un análisis estructuralista sustentado en la "búsqueda de un nivel homogéneo de sentido, una coherencia en el plano del significado basada en la reiteración de un unidades semánticas idénticas" (p. 138). Al situarse frente a un discurso publicitario habría que abstraer "el/los sema/s redundantes/s y computar la frecuencia de su reiteración" (p. 142), identificar el sistema de signos que comunican esta isotopía en el anuncio y, en tercer lugar, "aportar evidencia extra-textual sobre la naturaleza semántica del mensaje" (p. 143).

Los dos capítulos que cierran el libro sitúan el análisis del mensaje publicitario en marcos referenciales concretos. Así, el capítulo ocho trata sobre las categorías de la transtextualidad de Gérard Genette, una herramienta que permitirá al analista reconocer "qué otros textos están siendo objeto de apelación" (p. 151). Genette proponía cinco tipos de relaciones transtextuales: la intertextualidad (co-presencia de un texto en otro texto), la paratextualidad (elementos circundantes al texto), metatextualidad (un texto comentando otro texto), architextualidad (un texto dependiente de un conjunto más amplio) e hipertextualidad (un texto que deriva de otro anterior). Para no caer en los peligros de una concepción holística de la transtextualidad, Pineda recuerda que "únicamente son pertinentes aquellas realidades que se han encarnado en forma textual" en el anuncio (p. 164). A partir de ahí, se trata de reconocer el ante-texto y el post-texto, así como la relación que el uno mantiene con el otro.

Finalmente, el capítulo nueve aborda la mitocrítica de la publicidad, ahondando de este modo en la connotación del mensaje. "La idea básica [...] es que el mito adquiere diferentes manifestaciones según el momento histórico, pudiendo decirse que existen estructuras de significación en la cultura que se manifiestan actualizadas en discursos diversos" (p. 185). En el análisis, se parte de la mitohermenéutica publicitaria, que consiste en "descifrar un mensaje oculto, no-aparente, y que suele estar codificado en el mensaje mediante procedimientos de tipo metafórico o alegórico" (p. 181). No obstante, la densa interpretación hermenéutica que pudiera suscitar esta metodología se contrarresta con la aparición del análisis estructuralista en lo que se conoce como mitocrítica del mensaje, para lo que se requiere la identificación de los mitemas en el discurso como unidades analíticas. Estos mitemas pueden ser, como sintetiza Pineda, hechos o acciones, situaciones, decoraciones míticas, 
personajes, temas u objetos emblemáticos (pp. 188-189). En un nivel más interpretativo, se podría aplicar posteriormente el mitoanálisis, el cual trae consigo consideraciones psicológicas, sociológicas y culturales más amplias circundantes al texto publicitario.

Análisis del mensaje publicitario culmina con unas consideraciones generales a modo de capítulo décimo, en las que Antonio Pineda establece una serie de ideas comunes a tener en cuenta en todos los modelos, agrupando luego de manera relacional las herramientas presentadas.

La obra, que aunque se presenta principalmente como un manual universitario resulta cautivadora para todo aquel interesado en el mensaje publicitario, supone un recorrido por diversos modelos y teorías semióticas cuya densidad académica Antonio Pineda, como profesor de Análisis del Discurso Publicitario en la Universidad de Sevilla, ha sabido sintetizar y pautar magistralmente. El autor no ha dejado de utilizar en cada capítulo ejemplos publicitarios reales con los que poner en práctica la metodología descrita, los cuales, ilustrando amenamente la lectura, se encuentran en el anexo de imágenes a color ubicado en las páginas finales del libro. A este recurrente recurso se le une un apartado específico en casi todos los capítulos sobre las implicaciones que el uso de cada metodología tiene para la publicidad, apartado a través del cual la lectora o lector aprehende la teoría explicada afianzando el procedimiento analítico. En este sentido, además, las nueve herramientas se cierran con un resumen numerado de los pasos del análisis a seguir en cada caso. Todo ello presentado en la calidad editorial a la Advook nos tiene acostumbrados, haciendo de la lectura una experiencia además de provechosa, altamente placentera.

En definitiva, en Análisis del mensaje publicitario Antonio Pineda ha puesto a disposición del público un despliegue de instrumental analítico con el que la publicidad queda despiezada hasta los niveles más exigentes. Lejos de ser un recorrido teórico denso por cada propuesta semiótica, por primera vez, el público sostiene una necesaria compilación sintética sobre cómo proceder al enfrentarse al mensaje publicitario. 